\title{
THE USE OF ICT IN THE MORAL EDUCATION OF PRESCHOOLERS: PROBLEMS AND FINDINGS
}

\author{
Liubov Lokhvytska ${ }^{1}$ \\ Iryna Potoshna ${ }^{2}$
}

DOI: https://doi.org/10.30525/978-9934-26-050-6-49

The urgency of the issue of moral education of preschool children is due to a number of factors, which gives grounds for outlining its importance and finding effective tools in the implementation of priority tasks. It is during the preschool childhood, as noted in the new version of the Basic Component (State Standard of Preschool Education), that the moral growth of personality takes place (educational areas: «Personality of the child» and «Child in society») [1]. Accordingly, educators of preschool education institutions should stimulate the formation of moral concepts and moral judgments, moral feelings and emotions, moral actions and moral behavior in preschool children, which in their entirety constitute the moral self-consciousness of the preschooler. In general, moral education contributes to the formation of a harmonious personality, which is aware of and accepts in the internal plan of action moral norms and is guided by moral values that determine the basis of interpersonal relationships.

The issues of finding effective means to fulfill the tasks of moral education of preschool children, which are set out in the partial program «Treasury of Morality» deserve attention [3]. Without denying the traditional ones, we will focus on the use of innovative, in particular, information and communication technologies (ICT). According to studies by many foreign scientists (L. Chen et al., 2018; Masoumi, 2015; Nikolopoulou \& Gialamas, 2015; Wang \& Hoot, 2006), the use of ICT helps to expand children's perception of information, which, in turn, stimulates the development of the preschooler's personality, its capabilities and needs $[2 ; 4 ; 5 ; 6]$.

The integration of ICT in the educational process of preschool education institutions contributes to the expansion of its content. Thus, information of moral orientation becomes more accessible for perception by preschool children. Bright pictures-images, musical or verbal accompaniment on the monitor screen allows to activate children, to pass from explanatoryillustrative way of information content to activity, in which the child from his own experience begins to tell about moral situations that happened to him. Thus, the moral education of preschoolers with the use of ICT should be, on

\footnotetext{
${ }^{1}$ Hryhorii Skovoroda University in Pereiaslav, Ukraine

${ }^{2}$ Hryhorii Skovoroda University in Pereiaslav, Ukraine
} 
the one hand, interesting for children and, on the other hand, productive in the implementation of the tasks set by the educator.

Among a number of significant amounts of ICT, the most accessible for use in the educational process of preschool institutions are YouTube and audio stories. In particular, YouTube is perhaps the most convenient and easiest means of ICT to be used with preschool children. YouTube provides a wide selection of videos to watch according to the moral content provided to children. Preschool educators can post amateur videos on YouTube on their own, which reveal the plot of a situation of moral content (for example, fairytale or literary characters) that may take place in the real life of their pupils. Audio tales - tales in on-line format on moral and ethical topics with musical accompaniment on special web-resources.

The purpose of the research was to select and test available for the perception of preschoolers ICT for the implementation of the tasks of moral education in the educational process of preschool education. The main means of using ICT are materials of the YouTube channel and audio-tales in on-line format on the topics of moral content, their discussion and analysis with older preschool children. Methods of conducting the formative stage of the experiment, planned for 2020-2021 provided for the conclusion of a system of ICT use in accordance with the objectives of the program of moral education [3]. We offer a brief description of it (see Table 1).

The use of ICT provides the formation of children's moral attitudes and moral values under the influence of informing them: raising awareness of moral norms, providing primary ideas about good and evil, standards of proper (or inappropriate) behavior. During such work, preschoolers compare themselves with the characters on the screens, analyze their behavior, moral self-esteem of their own actions. Thus, the practical implementation of ICT in the process of moral education of preschool children involves the development of a special system of appropriate resources in order to ensure the moral growth of each individual, based on the characteristics of the child's moral development, moral needs, requests, etc. ICTs make it possible to implement effectively the tasks of moral education of preschoolers. 
Table 1

The system of using ICT in the moral education of preschool children (on the example of the senior group)

\begin{tabular}{|c|c|c|}
\hline $\begin{array}{c}\text { Program } \\
\text { section } \\
\text { «Treasury of } \\
\text { morality» [3] } \\
\text { (thematic } \\
\text { direction) } \\
\end{array}$ & Main program tasks & Name and URL of the resource \\
\hline 1 & 2 & 3 \\
\hline $\begin{array}{l}\text { To know } \\
\text { about } \\
\text { morality - to } \\
\text { avoid troubles }\end{array}$ & $\begin{array}{l}\text { - to teach children to } \\
\text { behave in accordance } \\
\text { with the norms of } \\
\text { morality on an } \\
\text { independent basis; } \\
\text { - to form conformity } \\
\text { in the attitude to the } \\
\text { observance or } \\
\text { violation of generally } \\
\text { accepted norms and } \\
\text { principles of morality }\end{array}$ & $\begin{array}{l}\text { Instructive videos of history. Useful tips. } \\
\text { «True or false» https://www.youtube.com/ } \\
\text { watch?v=USSkn3XIIic\&list=PLmMdc5Et } \\
\text { RgSgAttgtRF_hbsRiAoVF4Hub\&index=33 } \\
\text { Evening stories. Honesty } \\
\text { https://www.youtube.com/watch?v=S1Rtzt } \\
\text { OCa14 } \\
\text { Audio tales: «Rabbit chill» http://deti.e- } \\
\text { papa.com.ua/dytyachi-pisni/6/9306.html } \\
\text { «Chanterelle and crane» http://deti.e- } \\
\text { papa.com.ua/dytyachi-pisni/6/9248.html }\end{array}$ \\
\hline $\begin{array}{l}\text { Respect } \\
\text { adults and } \\
\text { grow polite }\end{array}$ & $\begin{array}{l}\text { - continue to cultivate } \\
\text { a respectful attitude } \\
\text { towards the environ- } \\
\text { ment (relatives, friends); } \\
\text { - support the desire of } \\
\text { children to show } \\
\text { sensitivity and } \\
\text { attention to family } \\
\text { and adults; } \\
\text { - cultivate gratitude } \\
\text { for the care of elders }\end{array}$ & $\begin{array}{l}\text { Useful hints. «One day of adult life» } \\
\text { https://www.youtube.com/watch?v=lqOGRtpq } \\
\text { 3ow } \\
\text { Useful tips. «How to understand another» } \\
\text { https://www.youtube.com/watch?v=iovMqYw } \\
\text { 4iIU } \\
\text { Evening stories. Respect } \\
\text { https://www.youtube.com/watch?v=ZcYX2bw } \\
\text { 1Dmk } \\
\text { Audio fairy tale «Mrs. Blizzard» http://deti.e- } \\
\text { papa.com.ua/dytyachi-pisni/6/9284.html }\end{array}$ \\
\hline $\begin{array}{l}\text { To live } \\
\text { together with } \\
\text { children and } \\
\text { understand } \\
\text { them }\end{array}$ & $\begin{array}{l}\text { - to form a friendly } \\
\text { attitude to peers, } \\
\text { respect for their rights } \\
\text { and interests on the } \\
\text { basis of morality; } \\
\text { - develop in children } \\
\text { the desire to act in the } \\
\text { interests of a partner } \\
\text { or group of peers; } \\
\text { - support children's } \\
\text { ability to exercise } \\
\text { moral self-control }\end{array}$ & $\begin{array}{l}\text { Instructional video stories. Useful tips. } \\
\text { «Friends» } \\
\text { https://www.youtube.com/watch? } \\
\text { v=au6zMAyHHmc } \\
\text { «How to understand another» } \\
\text { https://www.youtube.com/watch?v=iovMq } \\
\text { YW4iIU } \\
\text { «What is a real friend?» } \\
\text { https://www.youtube.com/watch?v=TAbmg } \\
\text { JYI8pE } \\
\text { «Brothers and sisters. How to make } \\
\text { friends» }\end{array}$ \\
\hline
\end{tabular}


(Continuation of Table 1)

\begin{tabular}{|c|c|c|}
\hline 1 & 2 & 3 \\
\hline & & $\begin{array}{l}\text { https://www.youtube.com/watch?v=qHwx } \\
\text { Hc7HXJo } \\
\text { «If they are not friends with you» } \\
\text { https://www.youtube.com/watch?v=hR8wx } \\
\text { kEcCnk } \\
\text { «Giraffe and Rhino» http://deti.e- } \\
\text { papa.com.ua/dytyachi-pisni/6/9371.html }\end{array}$ \\
\hline $\begin{array}{l}\text { Trust and co- } \\
\text { experience }\end{array}$ & $\begin{array}{l}\text { - to form the ability to } \\
\text { show understanding, } \\
\text { sympathy and } \\
\text { friendliness in } \\
\text { relationships with } \\
\text { others; } \\
\text { - learn to provide } \\
\text { emotional support to } \\
\text { peers in case of } \\
\text { certain difficulties; } \\
\text { - support empathy in } \\
\text { children }\end{array}$ & $\begin{array}{l}\text { Instructive videos of history. Useful tips. } \\
\text { «Brand new» } \\
\text { https://www.youtube.com/watch?v=2zM_K } \\
\text { DVgUP8 } \\
\text { Ropes. A story about friendship } \\
\text { https://www.youtube.com/watch?v=S_Q0B } \\
\text { yWT8lg } \\
\text { Video story «Nightingale with one wing» } \\
\text { https://www.youtube.com/watch?v=nmgKP } \\
\text { eKPufk } \\
\text { Social video «Rich boy and shoes» } \\
\text { https://www.youtube.com/watch?v=9btXLv } \\
\text { kHqVo }\end{array}$ \\
\hline $\begin{array}{l}\text { Acquire good } \\
\text { manners and } \\
\text { become polite }\end{array}$ & $\begin{array}{l}\text { - encourage the use of } \\
\text { polite words in speech } \\
\text { during conversations, } \\
\text { appeals, requests, etc.; } \\
\text { - to reveal the } \\
\text { importance of the } \\
\text { native language in the } \\
\text { process of forming the } \\
\text { foundations of } \\
\text { morality; } \\
\text { - to stimulate in } \\
\text { children signs of a } \\
\text { friendly form of } \\
\text { expressions of offers, } \\
\text { councils, requests, etc. }\end{array}$ & $\begin{array}{l}\text { Instructive video stories. Useful tips. } \\
\text { «How to become responsible» } \\
\text { https://www.youtube.com/watch?v=LDBE9 } \\
\text { GsqHB8 } \\
\text { «To fight or not to fight» } \\
\text { https://www.youtube.com/watch?v=J4kAW } \\
\text { eNtKZ0 } \\
\text { «If you did a bad deed» } \\
\text { https://www.youtube.com/watch?v=213jhd } \\
\text { gAF1s } \\
\text { «Tears and cries» } \\
\text { https://www.youtube.com/watch?v=Hhn5S } \\
\text { 7FVaqg\&list=PLmMdc5EtRgSgAttgtRF_h } \\
\text { bsRiAoVF4Hub\&index=22 } \\
\text { «About whims and brawls» } \\
\text { https://www.youtube.com/watch?v=LKYi7 } \\
\text { pU0lPM } \\
\text { Audio fairy tale «Hare and Hedgehog» } \\
\text { http://deti.e-papa.com.ua/dytyachi- } \\
\text { pisni/6/69.html }\end{array}$ \\
\hline
\end{tabular}


(Continuation of Table 1)

\begin{tabular}{|c|c|c|}
\hline 1 & 2 & 3 \\
\hline $\begin{array}{l}\text { Do good } \\
\text { deeds and } \\
\text { always } \\
\text { rejoice in } \\
\text { them }\end{array}$ & $\begin{array}{l}\text { - stimulate the ability } \\
\text { to make the right } \\
\text { moral choices, which } \\
\text { is a prerequisite for } \\
\text { moral actions; } \\
\text { - explain the } \\
\text { consequences (joys or } \\
\text { sorrows) of the } \\
\text { implementation or } \\
\text { violation of all available } \\
\text { rules and familiar rules; } \\
\text { - to develop a } \\
\text { personal attitude to } \\
\text { the observance and } \\
\text { violation of moral } \\
\text { norms }\end{array}$ & $\begin{array}{l}\text { Useful tips. } \\
\text { «The cycle of good in nature» } \\
\text { https://www.youtube.com/watch?v=yXEbK } \\
\text { dpyaUk } \\
\text { Useful tips. } \\
\text { «If they are not friends with you» } \\
\text { https://www.youtube.com/watch?v=hR8wx } \\
\text { kEcCnk } \\
\text { Useful tips. } \\
\text { «If you did a bad deed» } \\
\text { https://www.youtube.com/watch?v=213jhd } \\
\text { gAF1s } \\
\text { Audio fairy tale «A tale of joy. Gifted joy» } \\
\text { https://www.youtube.com/watch?v=- } \\
\text { aqN4PuKzdo }\end{array}$ \\
\hline $\begin{array}{l}\text { To be in } \\
\text { harmony is to } \\
\text { forget about } \\
\text { insults }\end{array}$ & $\begin{array}{l}\text { - develop children's } \\
\text { desire to express their } \\
\text { (morally acceptable) } \\
\text { position and attitude } \\
\text { to what is happening } \\
\text { around; } \\
\text { - teach children to } \\
\text { objectively perceive a } \\
\text { positive and negative } \\
\text { assessment of their } \\
\text { worthy (or vice versa) }\end{array}$ & $\begin{array}{l}\text { Instructive video stories. Useful tips. } \\
\text { «School of good mood» } \\
\text { https://www.youtube.com/watch?v=kUY- } \\
\text { QzskELk } \\
\text { «Make peace, make peace!» } \\
\text { https://www.youtube.com/watch?v=MASn } \\
\text { ZdHRc6s } \\
\text { Audio fairy tale «Little Mitsik» } \\
\text { http://deti.e-papa.com.ua/dytyachi- } \\
\text { pisni/6/9374.html } \\
\text { «The Parable of the Good» } \\
\text { https://www.youtube.com/watch?v=SHqeG } \\
\text { 2w10mA }\end{array}$ \\
\hline $\begin{array}{l}\text { Evaluate } \\
\text { yourself and } \\
\text { make it better }\end{array}$ & $\begin{array}{l}\text { - to form the ability to } \\
\text { evaluate one's own } \\
\text { moral qualities, } \\
\text { actions (ability to } \\
\text { negatively evaluate } \\
\text { one's own violations } \\
\text { of moral norms); } \\
\text { - to develop } \\
\text { independence and } \\
\text { criticality of } \\
\text { children's assessment } \\
\text { and self-assessment, } \\
\text { the ability to }\end{array}$ & $\begin{array}{l}\text { Instructive video stories. Useful tips. } \\
\text { «The one who lives inside you» } \\
\text { https://www.youtube.com/watch?v=jw5Mj } \\
\text { bGPTLE } \\
\text { «If you did a bad deed» } \\
\text { https://www.youtube.com/watch?list=PLm } \\
\text { Mdc5EtRgSgAttgtRF_hbsRiAoVF4Hub\&v } \\
=213 j h d g A F 1 s \\
\text { «About insults» } \\
\text { https://www.youtube.com/watch?v=rQNyIt } \\
\text { qSfmo\&list=PLmMdc5EtRgSgAttgtRF_hb } \\
\text { sRiAoVF4Hub\&index=51 } \\
\text { «Great green envy» }\end{array}$ \\
\hline
\end{tabular}


(End of Table 1)

\begin{tabular}{|l|l|l|}
\hline $\mathbf{1}$ & \multicolumn{1}{|c|}{$\mathbf{2}$} & \multicolumn{1}{c|}{$\mathbf{3}$} \\
\hline & adequately assess the & https://www.youtube.com/watch?v=9u66Qj \\
& possibilities of their & s9lvM \\
& own influence on & «Anger. Punish or pardon» \\
& other people; & https://www.youtube.com/watch?v=S9gYG \\
& - to form children's & vC4Dt4 \\
& moral self-awareness & «About Greed and Generosity» \\
& & https://www.youtube.com/watch?v=qT7Yw \\
& & oRRtgE \\
& & «Shy or cautious» \\
& & https://www.youtube.com/watch?v=9Cj1pz \\
& & XsTpM \\
\hline & & \\
& & \\
&
\end{tabular}

\section{References:}

1. Bazovyj komponent doshkiljnoji osvity (Derzhavnyj standart doshkiljnoji osvity) [Basic component of preschool education (State standard of preschool education)]. Nakaz MON Ukrajiny № 33 vid 12.01.2021 r. Retrieved from: https://mon.gov.ua/storage/app/media/rizne/2021/12.01/Pro_novu_redaktsiyu\%20Bazo voho\%20komponenta\%20doshkilnoyi\%20osvity.pdf

2. Chen, L., Chen, T.-L., Lin, C.-J., \& Liu, H.-K. (2018). Preschool Teachers' Perception of the Application of Information Communication Technology (ICT) in Taiwan. Sustainability, 11(1), 114. https://doi.org/10.3390/su11010114

3. Lokhvytska, L. (2020). Proghrama z moraljnogho vykhovannja ditej doshkiljnogho viku «Skarbnycja morali» [The program for moral education of preschool children «Treasury of morality»] (2-ghe vyd. zi zmin. i dopovn.). Ternopilj: Mandrivecj.

4. Masoumi, D. (2015). Preschool teachers' use of ICTs: Towards a typology of practice. Contemporary Issues in Early Childhood, 16, 5-17. https://doi.org/ $10.1177 / 1463949114566753$

5. Nikolopoulou, K., \& Gialamas, V. (2015). ICT and play in preschool: early childhood teachers' beliefs and confidence. International Journal of Early Years Education, 23(4), 409-425. https://doi.org/10.1080/09669760.2015.1078727

6. Wang, X. C., \& Hoot, J. L. (Eds.). (2006). Information and Communication Technology in Early Childhood Education. Early Education and Development, 17(3), 317-322. https://doi.org/10.1207/s15566935eed1703_1 